\title{
Guanosine modulates SUMO2/3-ylation in neurons and astrocytes via adenosine receptors
}

\author{
Camila A. Zanella ${ }^{1} \cdot$ Carla I. Tasca $^{2} \cdot$ Jeremy M. Henley ${ }^{3} \cdot$ Kevin A. Wilkinson $^{3}$ (I) $\cdot$ Helena I. Cimarosti ${ }^{1}$
}

Received: 12 May 2020 / Accepted: 17 August 2020 / Published online: 5 September 2020

(C) The Author(s) 2020

\begin{abstract}
SUMOylation is a post-translational modification (PTM) whereby members of the Small Ubiquitin-like MOdifier (SUMO) family of proteins are conjugated to lysine residues in target proteins. SUMOylation has been implicated in a wide range of physiological and pathological processes, and much attention has been given to its role in neurodegenerative conditions. Due to its reported role in neuroprotection, pharmacological modulation of SUMOylation represents an attractive potential therapeutic strategy in a number of different brain disorders. However, very few compounds that target the SUMOylation pathway have been identified. Guanosine is an endogenous nucleoside with important neuromodulatory and neuroprotective effects. Experimental evidence has shown that guanosine can modulate different intracellular pathways, including PTMs. In the present study we examined whether guanosine alters global protein SUMOylation. Primary cortical neurons and astrocytes were treated with guanosine at $1,10,100,300$, or $500 \mu \mathrm{M}$ at four time points, $1,6,24$, or $48 \mathrm{~h}$. We show that guanosine increases global SUMO2/ 3 -ylation in neurons and astrocytes at $1 \mathrm{~h}$ at concentrations above $10 \mu \mathrm{M}$. The molecular mechanisms involved in this effect were evaluated in neurons. The guanosine-induced increase in global SUMO2/3-ylation was still observed in the presence of dipyridamole, which prevents guanosine internalization, demonstrating an extracellular guanosine-induced effect. Furthermore, the A1 adenosine receptor antagonist DPCPX abolished the guanosine-induced increase in SUMO2/3-ylation. The A2A adenosine receptor antagonist ZM241385 increased SUMOylation per se, but did not alter guanosine-induced SUMOylation, suggesting that guanosine may modulate SUMO2/3-ylation through an A1-A2A receptor interaction. Taken together, this is the first report to show guanosine as a SUMO2/3-ylation enhancer in astrocytes and neurons.
\end{abstract}

Keywords Astrocytes $\cdot$ Neurons $\cdot$ Post-translational modification $\cdot$ Purinergic system $\cdot$ SUMO

\section{Introduction}

SUMOylation is a post-translational modification (PTM) whereby the Small Ubiquitin-like MOdifier (SUMO) peptide is

Electronic supplementary material The online version of this article (https://doi.org/10.1007/s11302-020-09723-0) contains supplementary material, which is available to authorized users.

Kevin A. Wilkinson

kevin.wilkinson@bristol.ac.uk

$\triangle$ Helena I. Cimarosti

helena.cimarosti@ufsc.br

1 Department of Pharmacology, Federal University of Santa Catarina (UFSC), Florianópolis, SC, Brazil

2 Department of Biochemistry, UFSC, Florianópolis, SC, Brazil

3 School of Biochemistry, University of Bristol, Bristol, UK conjugated to target proteins at lysine residues [1]. SUMO conjugation to target proteins is mediated by a three-step, ATPdependent enzymatic cascade involving E1, E2, and E3 enzymes, and can be reversed by the actions of SUMO proteases, the most well characterized of which are the SENP family [1]. SUMOylation plays important physiological roles $[2,3]$ and, in neurons, has been shown to be crucial for synaptic plasticity and cellular communication [4-7]. We and others have shown that SUMOylation is part of an endogenous neuroprotective response in ischemic conditions [8-12]. Furthermore, several proteins implicated in ischemia [13], and neurodegenerative disorders [14], such as Alzheimer's [15-17] and Parkinson's diseases [18, 19], are SUMO targets, and SUMOylation has been linked to agerelated processes [20, 21]. As a result, SUMOylation may represent an attractive therapeutic target in several disorders. However, relatively few compounds that can target protein SUMOylation have so far been identified. 
Accumulating evidence has demonstrated that guanosine, an endogenous nucleoside, may be a therapeutically useful compound in a number of disorders [22-24]. Due to its role in fundamental cellular mechanisms, guanosine promotes many protective effects such as anti-inflammatory effects during aging in astrocytes [25] and is protective against in vivo amyloid-beta (A $\beta$ )-induced toxicity [26], seizures [27], and ischemia $[28,29]$. However, despite several studies reporting the protective effects of guanosine [22-24], little is known about the molecular mechanisms involved. We have recently shown that guanosine can prevent ischemia-induced increases in reactive oxygen species (ROS) and impairment of glutamate uptake [29]. Guanosine-mediated phosphorylation and, consequently, activation of $\mathrm{Akt} / \mathrm{PKB}$ and inactivation of glycogen synthase kinase $3 \beta$ (GSK3 $\beta$ ) seem to be crucial for its anti-apoptotic effects under cellular stress conditions caused by oxidative damage [30], glutamate [31], and staurosporine [32]. In addition, guanosine can stimulate neural stem cell proliferation via phosphorylation/activation of CREB [33], further suggesting that phosphorylation of proteins might contribute the molecular effects of guanosine.

Although a specific receptor for guanosine has not been identified [34], a number of reports suggest it may interact with adenosine receptors (A1 and A2A) [24, 29, 35-38]. Furthermore, the neuroprotective effect of guanosine was also suggested to be through the large conductance $\mathrm{Ca}^{2+}$-activated $\mathrm{K}^{+}$channel (BK) [30].

Here, we sought to evaluate whether guanosine may modulate global protein SUMOylation in neurons and astrocytes, and further determine whether adenosine receptors mediate these effects.

\section{Methods}

\section{Cell culture}

Cortical neurons were prepared as described previously [39]. Briefly, cortices from E18 Wistar rats were dissected in Hank's balanced salt solution (HBSS, Gibco) followed by trypsin and mechanical dissociation. Neurons $\left(55 \times 10^{4}\right.$ cells/well) were plated on 6-well plates previously treated with poly-L-lysine $(0.1 \mathrm{mg} / \mathrm{mL}$, Sigma). Plating medium consisted of Neurobasal Medium (Gibco) containing 10\% horse serum (Gibco), B27 (1×, Gibco), penicillin-streptomycin (P/S, 100 units penicillin and $0.1 \mathrm{mg} / \mathrm{mL}$ streptomycin; Thermo Scientific), and $5 \mathrm{mM}$ Glutamax (Gibco). After $24 \mathrm{~h}$, plating medium was replaced with $3 \mathrm{~mL}$ of feeding medium (Neurobasal Medium, B27, P/S, Glutamax) with no further medium changes. Neurons were used for experiments at 14 days in vitro. Cortical astrocytes were prepared as described previously [40]. Briefly, cortices from Wistar rats (0-2 days old) were dissected in PBS $(1 \times$, containing $1 \mathrm{mM}$ glucose) followed by mechanical dissociation. Astrocytes $\left(70 \times 10^{4}\right.$ cells per well) were plated on 6 -well plates previously treated with poly-L-lysine $(0.1 \mathrm{mg} / \mathrm{mL}$, Sigma). Plating medium consisted of Dulbecco's modified Eagle's medium (DMEM) nutrient mixture F-12 (Gibco), supplemented with $10 \%$ fetal bovine serum (Gibco). Cell culture medium was changed $24 \mathrm{~h}$ after plating and changed subsequently three times a week. Astrocytes were used for experiments at 14 days in vitro. Ethics committees previously approved all procedures used in this study (CEUA 955 - UFSC and UB/18/ 004 - University of Bristol).

\section{Drug treatments}

Unless otherwise specified, the drugs used in the experiments were obtained from Sigma: guanosine (G6752), adenosine (A9251), dipyridamole (10 $\mu \mathrm{M}$, D9766), DPCPX (100 nM, C101) and ZM 241385 (50 nM, Z0153). The concentration curves $(1,10,100,300$ and $500 \mu \mathrm{M})$ for guanosine, adenosine and guanine were based on previous studies $[29,30,36,41$, 42].

\section{Western blotting}

For immunoblotting, neurons and astrocytes were lysed in $250 \mu \mathrm{L}$ sample buffer solution $(1 \times)$ containing $2 \%$ SDS $(\mathrm{w} / \mathrm{v}), 5 \%$ glycerol (v/v), $62.5 \mathrm{mM}$ Tris- $\mathrm{HCl} \mathrm{pH} 6.8$, and 5\% $(\mathrm{v} / \mathrm{v}) \beta$-mercaptoethanol. Lysates were collected and heated to $95{ }^{\circ} \mathrm{C}$ for $10 \mathrm{~min}$ prior to gel electrophoresis. Proteins were separated by SDS-PAGE (10-15\% gels). PDVF membranes were blocked in $5 \%(\mathrm{w} / \mathrm{v})$ non-fat milk powder or bovine serum albumin (BSA, Sigma) in PBS-T. The following primary antibodies were incubated overnight at $4{ }^{\circ} \mathrm{C}$ : SUMO1 (1:1000, Cell Signaling, 4930), SUMO2/3 (1:1000, Cell Signaling, 4971S), SENP3 (1:1000, Cell Signaling, D20A10), and GAPDH (1:10000, Abcam, ab8248). Ponceau S (0.1\% in 5\% acetic acid, Sigma, P7170) was also used for protein staining [43]. After three washes with PBS-T, membranes were incubated with the following HRPconjugated secondary antibodies for $1 \mathrm{~h}$ at room temperature: anti-mouse (1:5000, Abcam, ab6728) or anti-rabbit (1:5000, Cell Signaling, 7074S). After three washes of $5 \mathrm{~min}$ each in PBS-T, proteins were visualized by enhanced chemiluminescence (Thermo Scientific). Protein bands were quantified by densitometry using ImageJ software (NIH) [44].

\section{Immunofluorescence}

For immunofluorescence, neurons and astrocytes were plated on glass coverslips $\left(1 \times 10^{5}\right.$ cells/well $)$ previously treated with nitric acid and poly-L-lysine $(0.1 \mathrm{mg} / \mathrm{mL})$. Neurons were washed with PBS once and fixed with $4 \%$ paraformaldehyde (PFA) for $20 \mathrm{~min}$. After three washes with PBS, PFA was 
quenched by incubation with PBS containing $20 \mathrm{mM}$ glycine for $10 \mathrm{~min}$, before cells were permeabilized with PBS containing $0.05 \%$ Triton for $5 \mathrm{~min}$. Next, blocking solution consisting of 5\% BSA diluted in PBS was added to the coverslips for $1 \mathrm{~h}$ at room temperature. Neurons were then incubated with anti- $\beta$ tubulin III (1:250, Sigma, T2200) and astrocytes with antiGFAP (1:100; Sigma-Aldrich, 3670S) for $1 \mathrm{~h}$. Cells were then washed twice with PBS containing $0.1 \%$ tween 20 for $5 \mathrm{~min}$ and incubated with Alexa Fluor 594 fluorescent antibodies (1:100, Invitrogen, A32740) for $1 \mathrm{~h}$ at room temperature. For nuclear staining, Hoechst 33342 was present in the mounting media. Images were acquired on a confocal microscope (Leica DMI6000 B, LCME-UFSC). To analyze morphology, three independent experiments were performed $[29,45]$.

\section{MTT assay}

Cell viability was assessed by the colorimetric MTT (3-(4,5dimethylthiazol-2-yl)-2,5-diphenyltetrazolium bromide) assay [46]. After the respective treatments, neurons and astrocytes were incubated with MTT $(0.2 \mathrm{mg} / \mathrm{mL})$ diluted in PBS and kept at $37{ }^{\circ} \mathrm{C}$ for $2 \mathrm{~h}$. MTT was removed and DMSO $(100 \%)$ added to cells. The absorbance was read at $540 \mathrm{~nm}$ in 96-well plates.

\section{Statistical analysis}

All results were included in the statistical analysis except for those significantly detected as outliers (https://www. graphpad.com/quickcalcs/Grubbs1.cfm). After confirming data normality (Kolmogorov-Smirnov test), one-way analysis of variance (ANOVA) was performed and Newman-Keuls was used as a post hoc test to determine significant differences among groups. Data are presented as mean + standard error of the mean (S.E.M.) and statistical significance expressed by ${ }^{*} p \leq 0.05,{ }^{* *} p \leq 0.01$, and ${ }^{* * *} p \leq 0.001$. GraphPad Prism 5 . 0 was used for graphs and statistics [44, 47].

\section{Results}

\section{Guanosine increases SUMO2/3 conjugation in neu- rons and astrocytes}

Although SUMOylation is a PTM known to be involved in a wide range of cellular functions [2, 3, 48], very few modulators of SUMOylation have been identified. Here we aimed to evaluate the putative modulatory effect of guanosine on SUMOylation. Guanosine $(10,100,300$, or $500 \mu \mathrm{M})$ increased global SUMO2/3 conjugation in neurons at $1 \mathrm{~h}$ (Fig. 1 a and e, $F=5014 ; p=0.001$ ). However, increased global SUMO2/3 conjugation was not observed at longer time points (Fig. $1 \mathrm{~b}-\mathrm{d}$ ), suggesting the effect of guanosine is transient and subsides by $6 \mathrm{~h}$. Moreover, we also observed an increase in levels of the SUMO protease SENP3, which removes SUMO2/3 from target proteins [49], after $6 \mathrm{~h}$ of treatment with $500 \mu \mathrm{M}$ guanosine, suggesting the transient nature of the guanosine-induced increase in $\mathrm{SUMO} 2 / 3$ conjugation may in part be due to compensatory increases in SUMO protease expression (Fig. $2 \mathrm{~b}$ and e, $F=3638$; $p=$ 0.018).

Considering the importance of astrocytes for the homeostasis and maintenance of neuronal function [50, 51], we also evaluated the effects of guanosine on protein SUMOylation in cortical astrocytes. Similarly to what we observed in neurons, guanosine increased global SUMO2/3 conjugation in astrocytes (at concentrations of 10, 100, 300, and $500 \mu \mathrm{M}, 1 \mathrm{~h}$ ) (Fig. 3 a and e, $F=9.025 ; p=0.0002$ ), but this effect was transient and not observed at later time points (Fig. $3 \mathrm{~b}-\mathrm{d}$ ). Together, these results demonstrate that guanosine can lead to a transient, reversible, increase in SUMO2/3 conjugation in both neurons and astrocytes. Conversely, however, guanosine $(500 \mu \mathrm{M})$ decreased global SUMO1 conjugation in neurons at $48 \mathrm{~h}$ (Fig. 4 $\mathrm{d}$ and h, $F=2851 ; p=0,047)$ and led to a similar trend towards decreased conjugation in astrocytes; however, this trend was not statistically significant (Supplementary Fig. 1 a-d).

\section{Guanosine does not affect cell viability of neurons or astrocytes}

Since SUMOylation has been shown to be increased by a number of cellular stressors [52], we wanted to confirm that guanosine was not causing cellular stress and affecting cell viability. Importantly, $1 \mathrm{~h}$ treatment with $500 \mu \mathrm{M}$ guanosine had no effect on cell viability in either astrocytes or neurons, as determined by MTT assay (Fig. 5 a and c, $F=2292 ; p=$ 0.1822). Furthermore, $48 \mathrm{~h}$ treatment with $100 \mu \mathrm{M}$ guanosine did not obviously affect astrocyte or neuronal morphology, as determined by GFAP or $\beta$-tubulin III staining, respectively (Fig. $5 \mathrm{~b}$ and d). Together, these data demonstrate that guanosine can enhance global SUMO2/3 conjugation without adversely affecting cell health.

\section{Guanosine effects on SUMOylation are extracellular- mediated}

Guanosine uptake is mediated through nucleoside transporters present in the cell membrane [53, 54]. In contrast, the SUMOylation proteins are intracellular components [3]. In order to investigate whether the mechanism by which guanosine increases global SUMOylation requires guanosine uptake, or is mediated by extracellular actions of guanosine, neurons were pre-incubated with dipyridamole $(10 \mu \mathrm{M})$, a pan-inhibitor of nucleoside transporters. Twenty minutes later, guanosine $(500 \mu \mathrm{M})$ was added in the presence of dipyridamole, and neurons were further incubated for an hour. As previously, SUMO1 

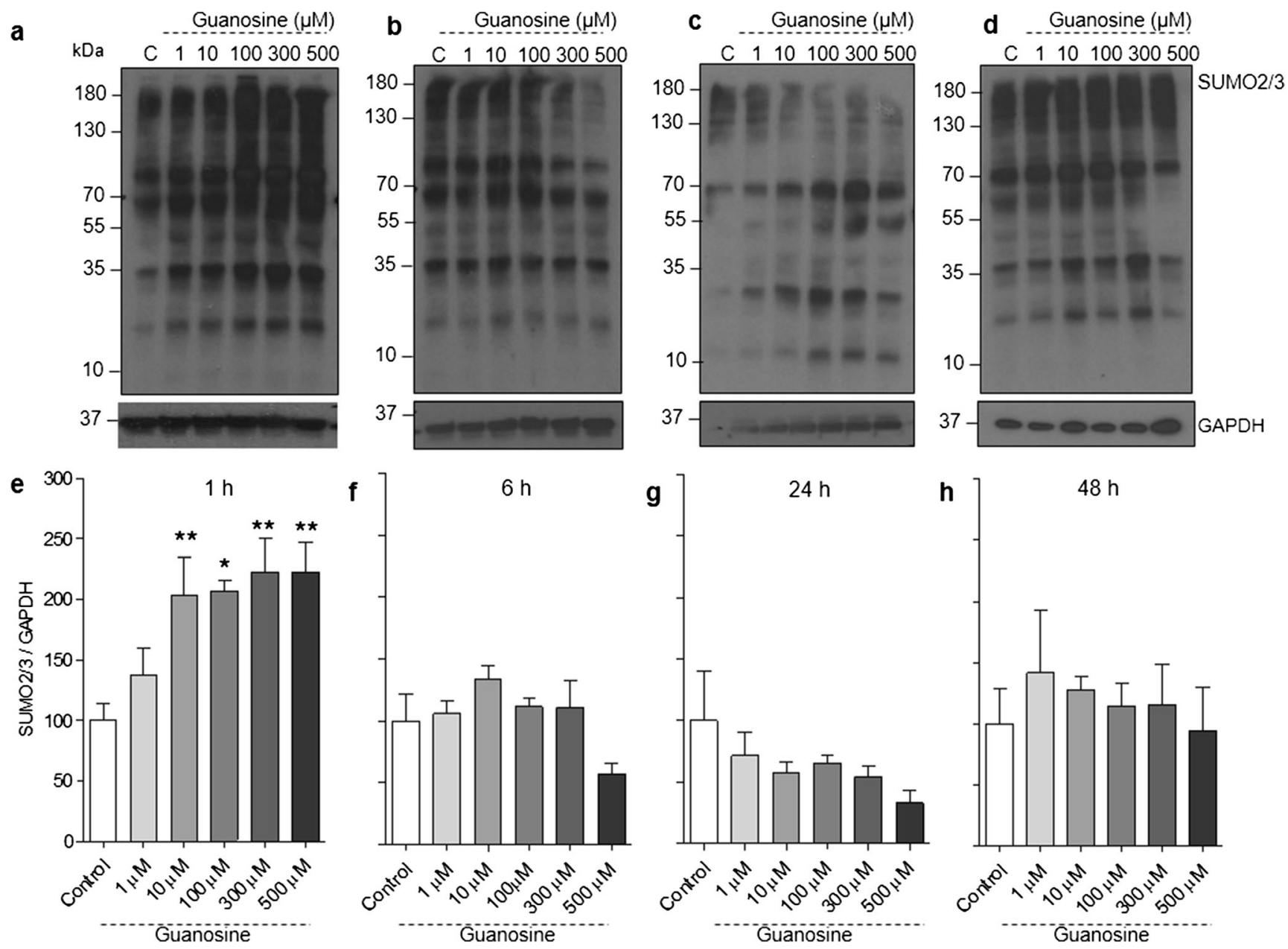

Fig. 1 Guanosine increases global SUMO2/3 conjugation in neurons. Representative SUMO2/3 Western blots from neurons treated with guanosine $(1-500 \mu \mathrm{M})$ for a $1 \mathrm{~h}, \mathbf{b} 6 \mathrm{~h}, \mathbf{c} 24 \mathrm{~h}$, and $\mathbf{d} 48 \mathrm{~h}$. b Optical density quantification of global SUMO2/3 conjugation for e $1 \mathrm{~h}, \mathbf{f} 6 \mathrm{~h}, \mathbf{g} 24 \mathrm{~h}$, and

conjugation remained unchanged (Fig. 6 a and c), but an increase in high molecular weight SUMO2/3 conjugates was observed both in the presence and absence of dipyridamole (Fig. $6 \mathrm{~b}$ and d, $F=3.444 ; p=0.0055)$. These results suggest that the guanosine-induced increase in SUMO2/3 conjugation does not require guanosine internalization and indicates that guanosine is acting through a membrane receptor interaction.

\section{The effects of guanosine on protein SUMOylation are mediated by adenosine $A 1$ receptors}

Next, we sought to investigate whether the guanosine-induced increase in global SUMO2/3 conjugation was mediated by $\mathrm{A} 1$ and/or A2A adenosine receptors. Neurons were treated with guanosine $(500 \mu \mathrm{M})$ in the presence or absence of the $\mathrm{A} 1$ receptor antagonist DPCPX $(100 \mathrm{nM})$ for $1 \mathrm{~h}$. DPCPX abolished the effect of guanosine on $\mathrm{SUMO} / 3$ conjugation (Fig. $7 \mathrm{a}$ and $\mathrm{c}, F=3.086 ; p=0.0571$ ), suggesting guanosine h 48 h. GAPDH was used as a loading control. Results expressed as mean + standard error of the mean $(n=3-5$ independent experiments). Oneway ANOVA followed by Newman-Keuls multiple comparison analyses $(* p<0.05, * * p<0.01$ vs. control). C, control; $\mathrm{kDa}$, kilodaltons

is enhancing SUMO2/3 conjugation through A1 receptors. In the same way, neurons were treated with guanosine in the presence or absence of the A2A antagonist ZM241385 $(50 \mathrm{nM})$ for $1 \mathrm{~h}$. ZM241385 did not affect the guanosineinduced increase in SUMO2/3 conjugation (Fig. $7 \mathrm{~b}$ and $\mathrm{d}$, $F=6.282 ; p=0.0051)$. However, ZM241385 per se increased global SUMO2/3 conjugation (Fig. 7 b and d). Surprisingly, adenosine treatment, at the same concentrations used for guanosine $(1,10,100,300$, and $500 \mu \mathrm{M})$, did not affect global protein SUMOylation by either SUMO1 (Supplementary Fig. 2 a and c, $F=0.371 ; p=0.85$ ) or SUMO2/3 (Supplementary Fig. $2 \mathrm{~b}$ and $\mathrm{d}, F=2.220 ; p=0.08$ ).

\section{Discussion}

Protein SUMOylation is a highly dynamic PTM $[3,55,56]$. Here, we demonstrate that guanosine induces an increase in 


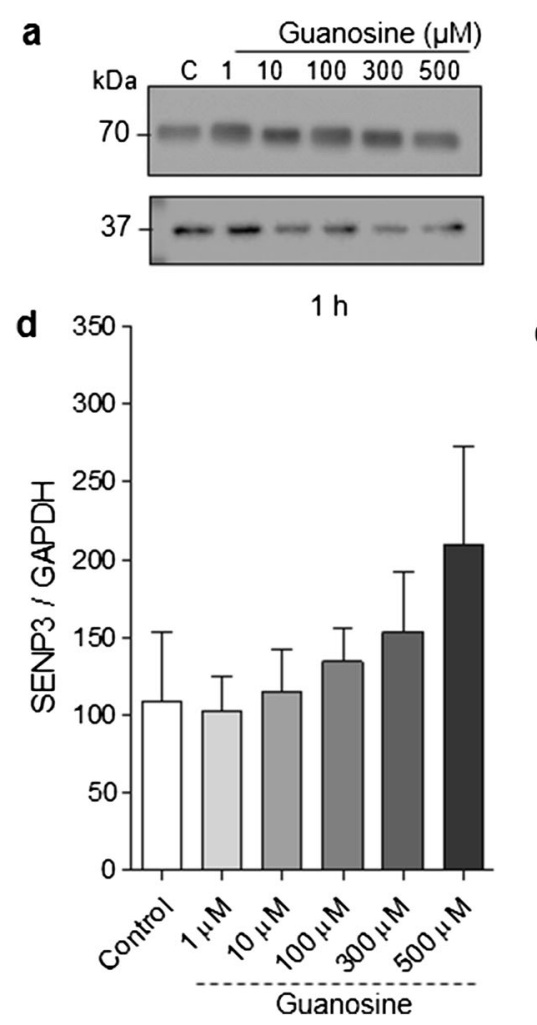

Fig. 2 Guanosine increases neuronal SENP3 levels. Representative SENP3 Western blots from neurons treated with guanosine $(1-500 \mu \mathrm{M})$ for $\mathbf{a} 1 \mathrm{~h}, \mathbf{b} 6 \mathrm{~h}$, and $\mathbf{c} 24 \mathrm{~h}$. Optical density quantification of SENP3 for d $1 \mathrm{~h}$, e $6 \mathrm{~h}$, and f $24 \mathrm{~h}$. GAPDH was used as a loading control. Results

global protein SUMO2/3 conjugation after $1 \mathrm{~h}$ stimulation with concentrations of guanosine of $10 \mu \mathrm{M}$ or higher. This effect was not observed at longer time points, suggesting this effect is transient and may ultimately be counteracted by a concomitant increase in levels of SENP3, a deSUMOylating enzyme that shows preference for deconjugating SUMO2/3 over other SUMO isoforms [49]. We cannot rule out the possibility that SUMO2/3 conjugation could return to control levels earlier than $6 \mathrm{~h}$; however, this will require further investigation. The consequences of both neuronal and astrocytic increases in SUMO2/3 conjugation after $1 \mathrm{~h}$ guanosine treatment, and the decrease in neuronal SUMO1 conjugation at $48 \mathrm{~h}$, need to be further investigated. However, importantly, we have demonstrated that guanosine stimulation does not lead to an observable loss of cellular viability or alteration of cell morphology.

A growing number of studies have demonstrated the importance of SUMO2/3 conjugation in mediating neuroprotective mechanisms [8, 57-59]. In a recent screen for compounds with SENP2 inhibitory activity, 6-thioguanine, which increases SUMO1-ylation and SUMO2/3-ylation levels, and the compound isoprenaline, which increases SUMO2/3ylation levels, were found to protect SH-SY5Y cells from oxygen and glucose deprivation, an in vitro model of ischemia [60]. As both 6-thioguanine [60] and guanosine, which was used in our study, increased SUMO2/3 conjugation, this effect may be related to similarities in their chemical structures. However, since our data demonstrate that guanosine uptake is not required for its effects on protein SUMOylation, it seems unlikely that the effects we observe are due to inhibition of intracellular SENP2.

Previous evidence has shown that there is more SUMO2/3 available to be conjugated to target proteins than SUMO1, which may explain the selective increase in SUMO2/3 conjugation at $1 \mathrm{~h}$ [52]. In Cos7 cells, there is approximately $40 \%$ more free SUMO2/3 than SUMO1 [52, 61, 62]; however, whether this is the case in neurons and astrocytes is not known. It is important to point out that some substrates may be modified only by SUMO1, or SUMO2/3, or both [63]. In this context, future investigations focusing on which cellular targets are being SUMOylated upon guanosine treatment will provide important information as to the functional consequences of the guanosine-induced increase in SUMO conjugation.

Under physiological conditions, extracellular guanosine is efficiently internalized [64]. Since the SUMOylation machinery is present intracellularly [3], we evaluated whether the effects of guanosine on SUMO conjugation required its internalization. Using dipyridamole to block guanosine internalization, we still observed an increase in SUMO2/3 conjugation 

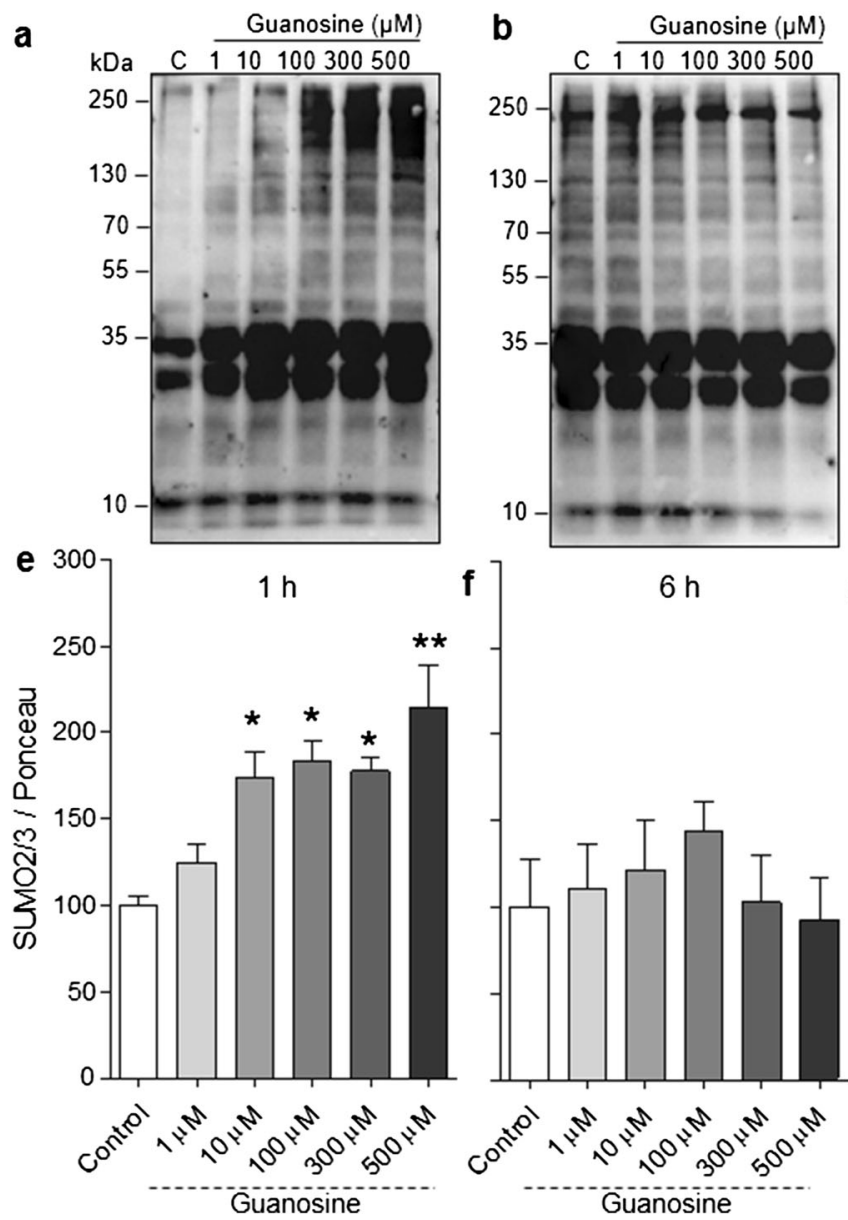

Fig. 3 Guanosine increases global SUMO2/3 conjugation in astrocytes. Representative SUMO2/3 Western blots from astrocytes treated with guanosine $(1-500 \mu \mathrm{M})$ for a $1 \mathrm{~h}, \mathbf{b} 6 \mathrm{~h}, \mathbf{c} 24 \mathrm{~h}$, and $\mathbf{d} 48 \mathrm{~h}$. Optical density quantification of global SUMO2/3 conjugation for $\mathbf{e} 1 \mathrm{~h}, \mathbf{f} 6 \mathrm{~h}, \mathbf{g} 24 \mathrm{~h}$, and h $48 \mathrm{~h}$. Ponceau staining was used as a loading control (Supplementary

in neurons. Similarly, in previous studies, blockade of nucleoside transporters did not impair guanosine-mediated prevention of apoptosis in cultured rat astrocytes [32], or the neurotrophic effects of guanosine in primary cultured cerebellar neurons [65]. These results strongly suggest that guanosine exerts its protective effects via an extracellular mechanism, which likely involves membrane receptor activation.

Previous studies from our group have demonstrated extracellular effects of guanosine acting through $\mathrm{A} 1$ and $\mathrm{A} 2 \mathrm{~A}$ adenosine receptors [30]. In the present study, A1 receptor blockade by DPCPX abolished the guanosine-induced increase in SUMO2/3 conjugation, suggesting that guanosine might be acting via A1 receptors. Regarding A2A receptor modulation with ZM241385, the antagonist itself increased SUMO2/3 conjugation, in a similar manner to guanosine, and co-incubation of ZM241385 plus guanosine did not further increase SUMO2/3-ylation compared with either compound alone. The effect of ZM241385 in enhancing SUMOylation per se suggests that constitutive A2A receptor activity might be directly modulating endogenous $\mathrm{SUMO} 2 / 3$
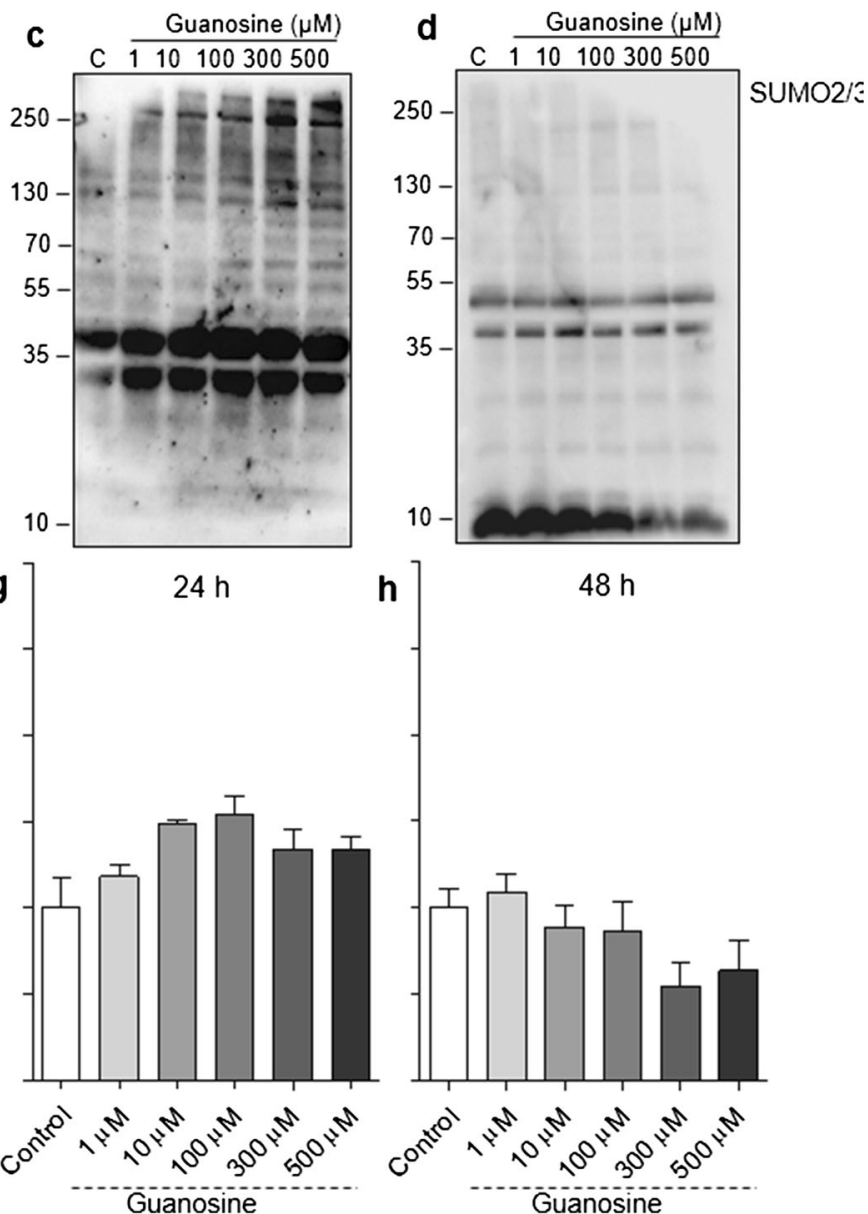

Fig. 1 D). Results expressed as mean + standard error of the mean $(n=3-$ 5 independent experiments). One-way ANOVA followed by NewmanKeuls multiple comparison analyses ( $* p<0.05, * * p<0.01$ vs. control). C, control; kDa, Kilodaltons

conjugation; however, this needs to be further experimentally confirmed. ZM241385 is classically described as an A2A receptor antagonist; however, some studies suggest that it can act also as an inverse agonist for A2A receptors [36, 66-68], which could explain its ability in promoting such an effect. Regarding the effect of guanosine, it is feasible that it may also act by reducing A2A receptor activity, similar to ZM241385, since we have previously shown its neuroprotective effect is not observed in A2A receptor-knockout mice [69]. Additionally, binding and functional studies in HEK293 cells transfected with $\mathrm{A} 1$ and $\mathrm{A} 2 \mathrm{~A}$ receptors showed guanosine did not interfere with $\mathrm{A} 1$ receptor-mediated signaling, and that it modulated A2A receptor binding and intracellular signaling only in cells co-expressing $\mathrm{A} 1$ and $\mathrm{A} 2 \mathrm{~A}$ receptors, providing the first piece of evidence that the effects of guanosine may occur through interaction with an oligomeric organization of adenosine receptors, namely the A1R-A2AR heteromer [69]. However, the exact mechanism of guanosine action is still unknown. Indeed, since guanosine reportedly shows low affinity for adenosine receptors [24], it remains possible that 

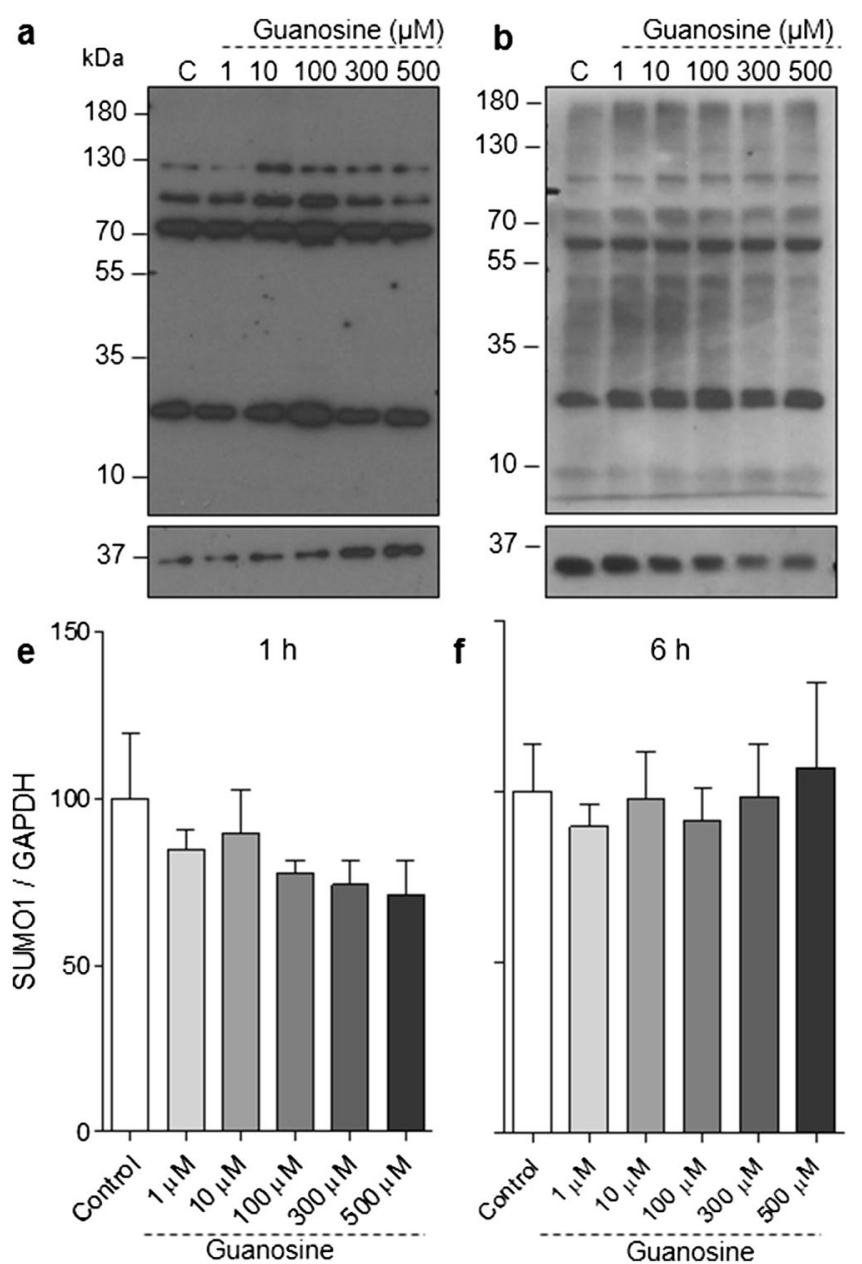

Fig. 4 Evaluation of guanosine effects on global SUMO1 conjugation in neurons. Representative SUMO1 Western blots from neurons treated with guanosine (1-500 $\mu \mathrm{M})$ for a $1 \mathrm{~h}, \mathbf{b} 6 \mathrm{~h}$, c $24 \mathrm{~h}$, and d $48 \mathrm{~h}$. Optical density quantification of global SUMO1 conjugation for $\mathbf{e} 1 \mathrm{~h}, \mathbf{f}$

guanosine acts via other receptor proteins [70], or via promoting the release of endogenous adenosine, as has been reported in some non-neural cell types $[71,72]$. Nonetheless, our data support a model whereby adenosine receptor activity is required for the effects of guanosine in promoting SUMOylation in neurons.

Since guanosine increased SUMO2/3 conjugation via adenosine receptors, we hypothesized that adenosine would promote a similar effect. Surprisingly, adenosine (1, 10, 100, 300, and $500 \mu \mathrm{M}$ ) for $1 \mathrm{~h}$ did not modulate global SUMO2/3 or SUMO1 conjugation. However, it remains possible that adenosine could modulate SUMOylation at shorter time points, especially considering that $\mathrm{G}$ protein-coupled receptors, such as adenosine receptors, may suffer from desensitization and internalization in response to continuous exposure to agonist, preventing the observation of downstream effects [73-75]. Another possible explanation is that guanosine may not promote desensitization of adenosine receptors since it is not their endogenous agonist. In addition, it has been suggested that guanosine can act as an
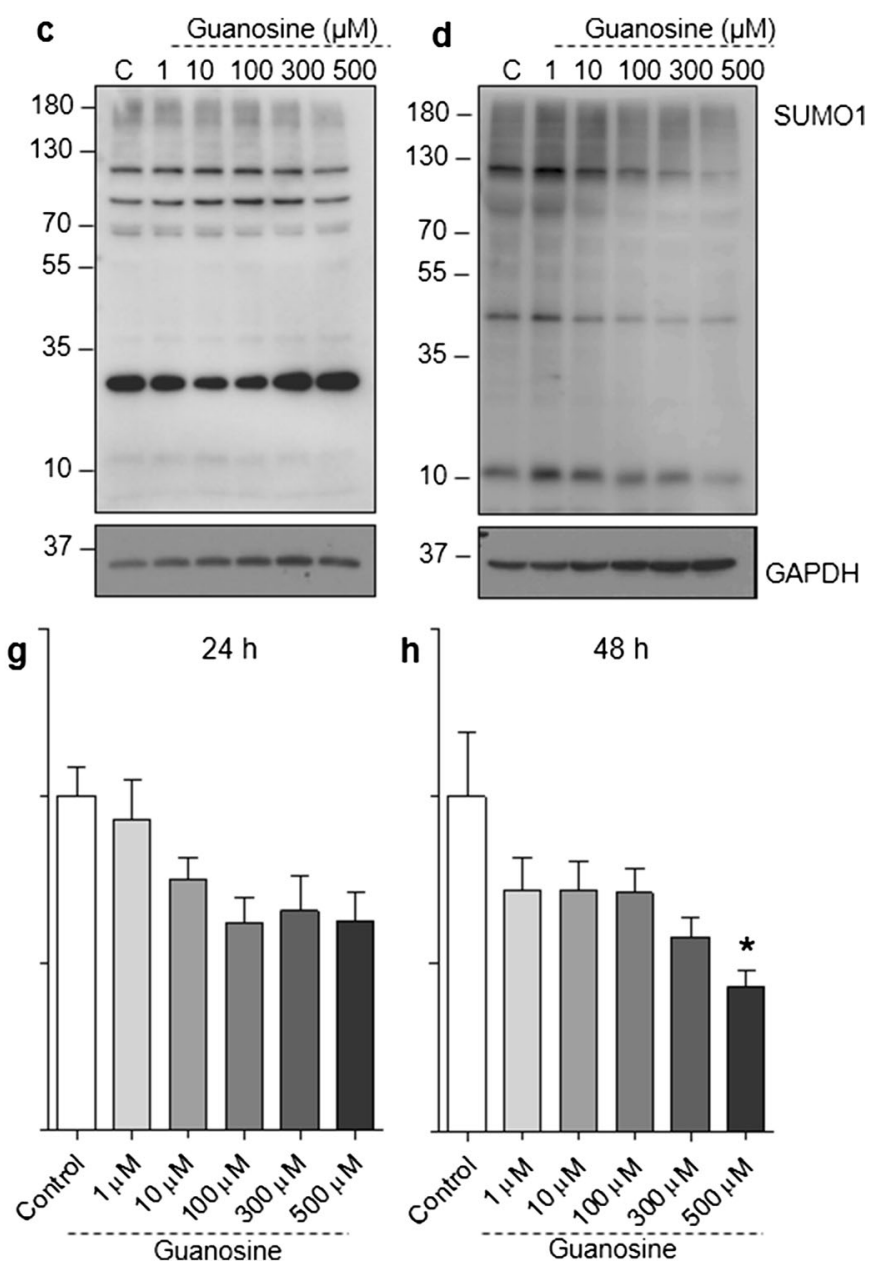

6 h, g 24 h, and h 48 h. GAPDH was used as a loading control. Results expressed as mean + standard error of the mean $(n=3-5$ independent experiments). One-way ANOVA followed by Newman-Keuls multiple comparison analyses ( $* p<0.05$ vs. control). C, control; $\mathrm{kDa}$, kilodaltons

allosteric modulator at adenosine receptors [24], suggesting it may therefore produce different effects to direct agonist activation with adenosine; however, this still needs further experimental confirmation.

To the best of our knowledge, there is, to date, only one experimental demonstration that SUMOylation can be modulated through adenosinergic signaling. The protein IкB $\alpha$ (nuclear factor of kappa light polypeptide gene enhancer in Bcells inhibitor, alpha), an important modulator of inflammatory responses, can be SUMO1-ylated in response to adenosine signaling. Following hypoxia and reoxygenation, there was an increase in SUMO1 conjugation to I $\mathrm{KB} \alpha$ in HeLa cells, and treatment with NECA, a non-specific adenosine receptor agonist, increased SUMO1 conjugation to $\mathrm{I} \kappa \mathrm{B} \alpha$ in a concentration-dependent manner. In contrast, a nonselective adenosine receptor antagonist, 8-phenyltheophylline, abolished NECA-induced I $\kappa \mathrm{B} \alpha$ SUMO1-ylation [76]. However, exactly how adenosine receptor activation leads to enhanced SUMOylation of $\mathrm{I} \kappa \mathrm{B} \alpha$ is unknown. 
Fig. 5 Guanosine does not affect astrocyte or neuronal viability and morphology. a Graph showing cellular viability (for MTT assay) of control and guanosine-treated astrocytes (500 $\mu \mathrm{M}, 1 \mathrm{~h}$ ). b Confocal images of control and guanosine-treated astrocytes $(100 \mu \mathrm{M}, 48 \mathrm{~h})$ stained for GFAP (glial fibrillary acidic protein, astrocytic marker) and DAPI (nuclear marker). c Graph showing cellular viability (for MTT assay) of control and guanosine-treated neurons $(500 \mu \mathrm{M}, 1 \mathrm{~h})$. d Confocal images of control and guanosine-treated neurons $(100 \mu \mathrm{M}, 48 \mathrm{~h})$ stained for $\beta$-tubulin III (neuronal marker) and DAPI (nuclear marker). Results expressed as mean \pm standard error of the mean ( $n=3$ independent experiments). One-way ANOVA did not identify any significant differences

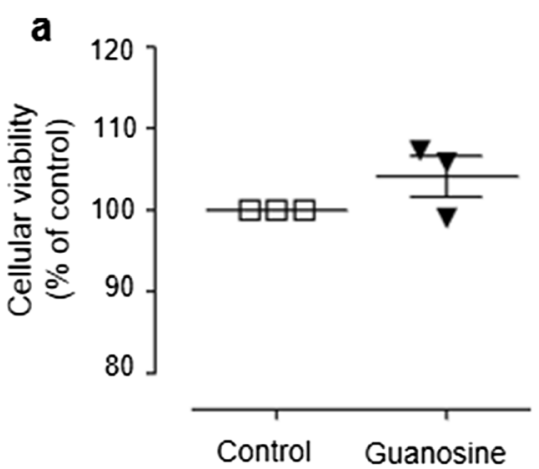

b

Astrocytes

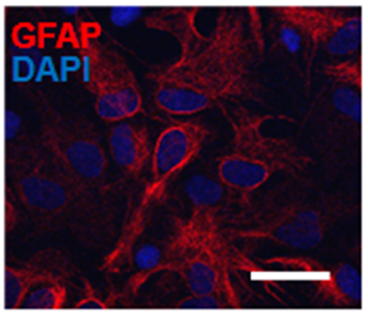

Control

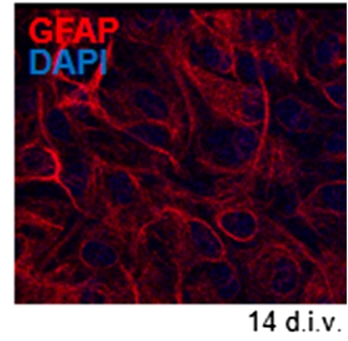

Guanosine

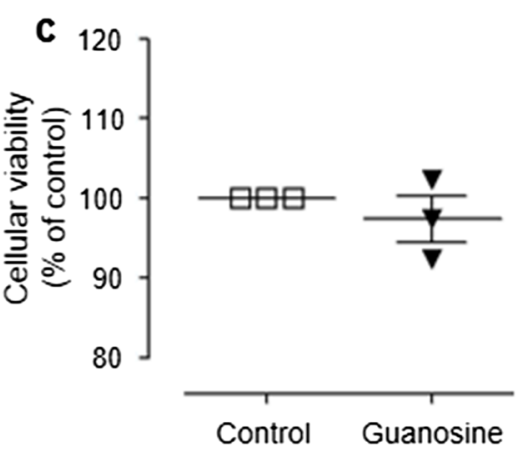

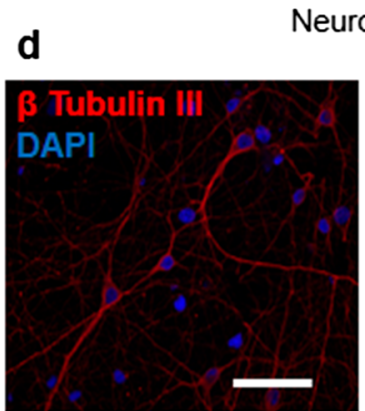

Control

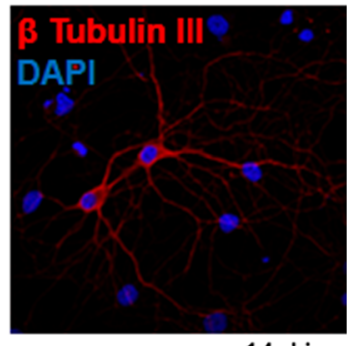

14 d.i.v.
Guanosine a
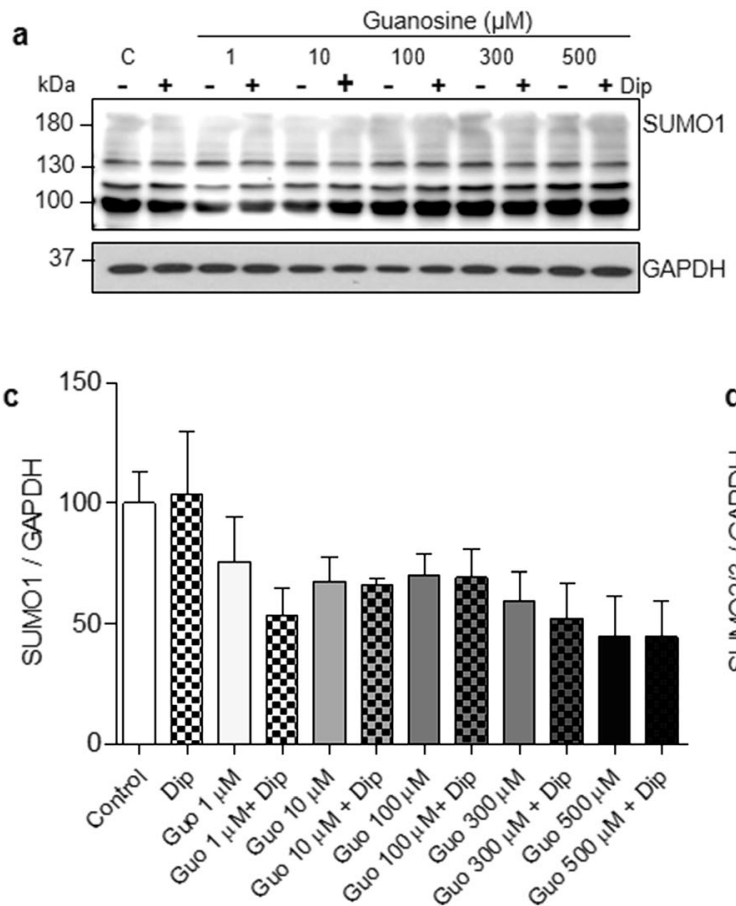

Fig. 6 Guanosine-mediated increases in neuronal SUMO2/3 conjugation occur via extracellular mechanisms. a Representative Western blots of high molecular weight a SUMO1 and b SUMO2/3-conjugated proteins and their respective optical density quantifications in $\mathbf{c}$ and $\mathbf{d}$. Neurons were co-incubated with dipyridamole (Dip, $10 \mu \mathrm{M})$ and guanosine $(1,10$,
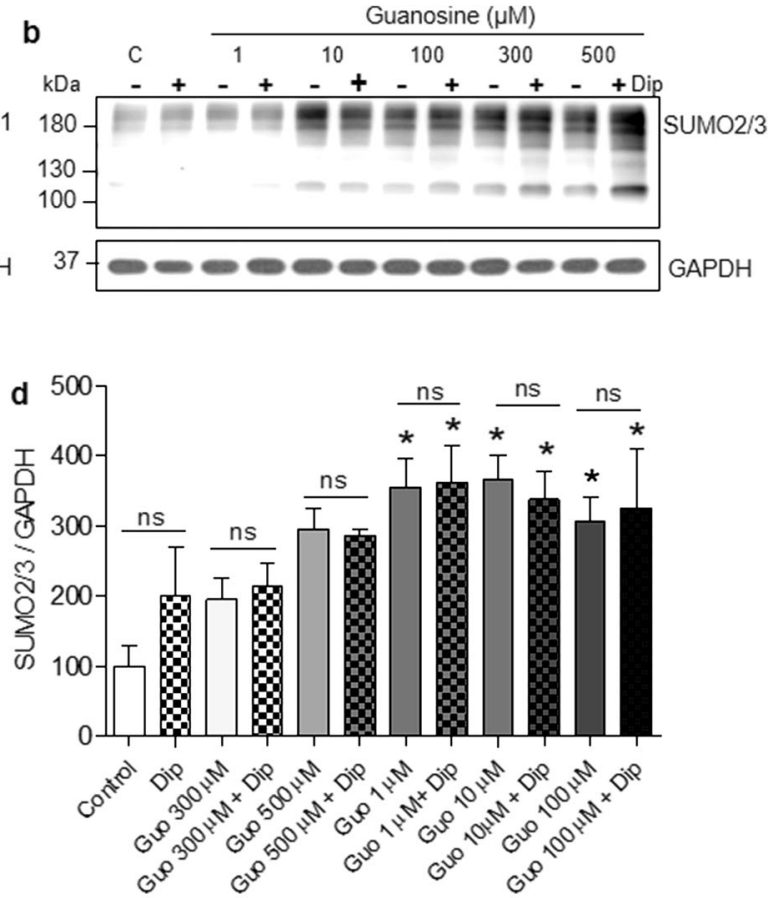

$100,300$, and $500 \mu \mathrm{M})$ for $1 \mathrm{~h}$. GAPDH was used as a loading control. Results expressed as mean + standard error of the mean $(n=3$ independent experiments). One-way ANOVA followed by Newman-Keuls multiple comparison analyses indicates the effects of the treatments with guanosine. $\mathrm{C}$, control; $\mathrm{kDa}$, kilodaltons 
Fig. 7 Guanosine increases neuronal SUMO2/3 conjugation via modulation of adenosine receptors. Neurons were coincubated with guanosine $(500 \mu \mathrm{M})$ and either a the adenosine A1 receptor antagonist DPCPX (100 nM) or b the A2A receptor antagonist ZM241385 (ZM) for $1 \mathrm{~h}$, followed by Western blotting for SUMO2/3. Quantification of data is shown in $\mathbf{c}$ (for DPCPX) and $\mathbf{d}$ (for ZM241385). One-way ANOVA followed by Newman-Keuls multiple comparison analyses indicates the effects of the treatments with guanosine (* $p<0.05$ vs. control). C, control; $\mathrm{G}$, guanosine; DP, DPCPX; kDa, kilodaltons a

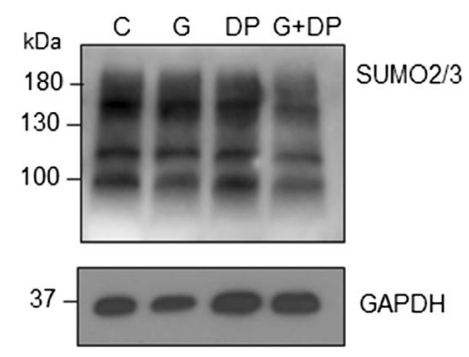

C

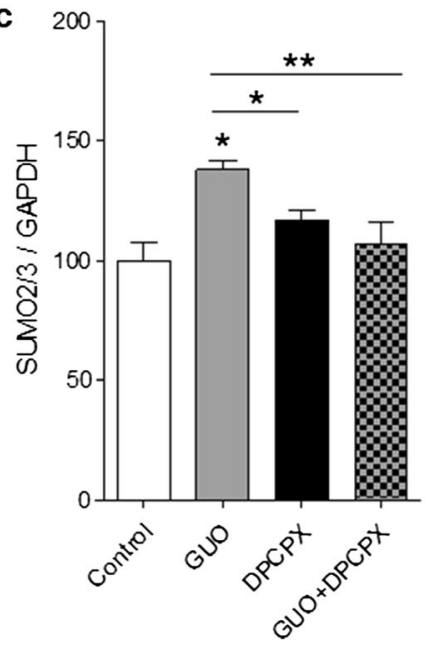

b

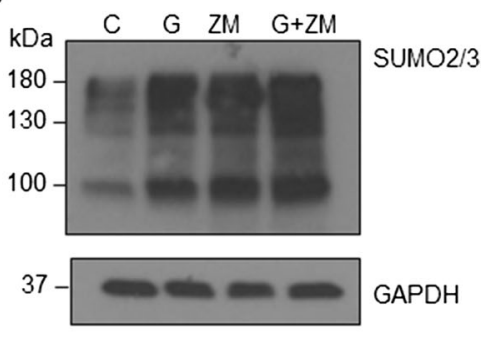

d

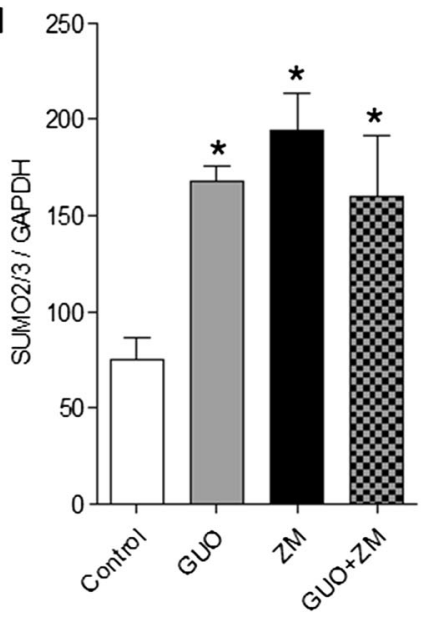

\section{Conclusion}

The importance of the SUMOylation pathway for neuronal function and dysfunction is well demonstrated in the literature $[3,77,78]$. Here we show for the first time that guanosine can increase global SUMO2/3 conjugation in neurons, in a manner that does not require its uptake into cells and which is dependent on the modulation of adenosine receptors, most likely the A1-A2A receptors. Despite much interest in SUMO as a possible therapeutic target, non-toxic modulators of SUMOylation are still scarce, although a few chemical compounds such as TAK-981 [79], ginkgolic acid [80], and tannic acid [81] have been shown to exert effects on global SUMO conjugation. Taken together, our results suggest that guanosine, an endogenous neuromodulator [23, 24, 82, 83], can lead to enhanced SUMO2/3-ylation, a phenomenon that has been shown to be neuroprotective against a number of cell stressors [3, 9, 13, 14, 16, 84]. Our findings therefore highlight guanosine as a potential therapeutic strategy to promote neuronal and glial survival.

Acknowledgments We thank LAMEB and LCME-UFSC laboratory facilities.

Funding This work was supported by grants from Brazilian agencies: Conselho Nacional de Desenvolvimento Científico e Tecnológico, $\mathrm{CNPq}$, and Coordenação de Aperfeiçoamento de Pessoal de Nível Superior, CAPES. We are also grateful for grant support from the
Newton Fund and the BBSRC (grant number BB/R00787X/1 to JMH and KAW).

\section{Compliance with ethical standards}

Conflict of interest The authors declare that they have no conflict of interest.

Ethical approval All the procedures used in this study were approved by the ethics committees from the respective universities: UFSC CEUA: 955 and University of Bristol: UB/18/004.

Open Access This article is licensed under a Creative Commons Attribution 4.0 International License, which permits use, sharing, adaptation, distribution and reproduction in any medium or format, as long as you give appropriate credit to the original author(s) and the source, provide a link to the Creative Commons licence, and indicate if changes were made. The images or other third party material in this article are included in the article's Creative Commons licence, unless indicated otherwise in a credit line to the material. If material is not included in the article's Creative Commons licence and your intended use is not permitted by statutory regulation or exceeds the permitted use, you will need to obtain permission directly from the copyright holder. To view a copy of this licence, visit http://creativecommons.org/licenses/by/4.0/.

\section{References}

1. Wilkinson KA, Henley JM (2010) Mechanisms, regulation and consequences of protein SUMOylation. Biochem J 428:133-145. https://doi.org/10.1042/BJ20100158 
2. Geiss-Friedlander R, Melchior F (2007) Concepts in sumoylation: a decade on. Nat Rev Mol Cell Biol 8:947-956. https://doi.org/10. $1038 /$ nrm2293

3. Henley JM, Craig TJ, Wilkinson KA (2014) Neuronal SUMOylation: mechanisms, physiology, and roles in neuronal dysfunction. Physiol Rev 94:1249-1285. https://doi.org/10.1152/ physrev.00008.2014

4. Martin S, Nishimune A, Mellor JR, Henley JM (2012) SUMOylation regulates kainate-receptor-mediated synaptic transmission. 447:321-325. https://doi.org/10.1038/nature05736. SUMOylation

5. Craig TJ, Anderson D, Evans AJ, Girach F, Henley JM (2015) SUMOylation of Syntaxin1A regulates presynaptic endocytosis. Sci Rep 5:1-11. https://doi.org/10.1038/srep17669

6. Matsuzaki S, Lee L, Knock E, Srikumar T, Sakurai M, Hazrati LN, Katayama T, Staniszewski A, Raught B, Arancio O, Fraser PE (2015) SUMO1 affects synaptic function, spine density and memory. Sci Rep 5:1-14. https://doi.org/10.1038/srep10730

7. Schorova L, Martin S (2016) SUMOylation in synaptic function and dysfunction. Front Synaptic Neurosci 8:1-24. https://doi.org/ 10.3389/fnsyn.2016.00009

8. Cimarosti H, Lindberg C, Bomholt SF, Rønn LCB, Henley JM (2008) Increased protein SUMOylation following focal cerebral ischemia. Neuropharmacology 54:280-289. https://doi.org/10. 1016/j.neuropharm.2007.09.010

9. Cimarosti H, Ashikaga E, Jaafari N, Dearden L, Rubin P, Wilkinson KA, Henley JM (2012) Enhanced SUMOylation and SENP-1 protein levels following oxygen and glucose deprivation in neurones. J Cereb Blood Flow Metab 32:17-22. https://doi.org/ 10.1038/jcbfm.2011.146

10. Lee YJ, Mou Y, Klimanis D, Bernstock JD, Hallenbeck JM (2014) Global SUMOylation is a molecular mechanism underlying hypothermia-induced ischemic tolerance. Front Cell Neurosci 8: 1-9. https://doi.org/10.3389/fncel.2014.00416

11. Zhang L, Liu X, Sheng H, et al (2018) Neuron-specific SUMO knockdown suppresses global gene expression response and worsens functional outcome after transient forebrain ischemia in mice. 190-212. https://doi.org/10.1016/j.neuroscience.2016.11. 036.NEURON-SPECIFIC

12. Zhang H, Huang D, Zhou J, Yue Y, Wang X (2019) SUMOylation participates in induction of ischemic tolerance in mice. Brain Res Bull 147:159-164. https://doi.org/10.1016/j.brainresbull.2019.02. 012

13. Silveirinha V, Stephens GJ, Cimarosti H (2013) Molecular targets underlying SUMO-mediated neuroprotection in brain ischemia. $\mathrm{J}$ Neurochem 127:580-591. https://doi.org/10.1111/jnc.12347

14. Anderson DB, Zanella CA, Henley JM, Cimarosti HI (2017) SUMO regulation of cellular processes - Google Books. https:// doi.org/10.1007/978-3-319-50044-7

15. Lee L, Dale E, Staniszewski A, Zhang H, Saeed F, Sakurai M, Fa' M, Orozco I, Michelassi F, Akpan N, Lehrer H, Arancio O (2014) Regulation of synaptic plasticity and cognition by SUMO in normal physiology and Alzheimer's disease. Sci Rep 4:1-13. https://doi. org/10.1038/srep07190

16. Hoppe JB, Salbego CG, Cimarosti H (2015) SUMOylation: novel neuroprotective approach for Alzheimer's disease? Aging Dis 6: 322-330. https://doi.org/10.14336/AD.2014.1205

17. Martins WC, Tasca CI, Cimarosti H (2016) Battling Alzheimer's disease: targeting SUMOylation-mediated pathways. Neurochem Res 41:568-578. https://doi.org/10.1007/s11064-015-1681-3

18. Guerra De Souza AC, Prediger RD, Cimarosti H (2016) SUMOregulated mitochondrial function in Parkinson's disease. J Neurochem 137:673-686. https://doi.org/10.1111/jnc.13599

19. Junqueira SC, Centeno EGZ, Wilkinson KA, Cimarosti H (2019) Post-translational modifications of Parkinson's disease-related proteins: phosphorylation, SUMOylation and Ubiquitination. Biochim
Biophys Acta Mol Basis Dis 1865:2001-2007. https://doi.org/10. 1016/j.bbadis.2018.10.025

20. Andreou AM, Tavernarakis N (2010) Protein metabolism and homeostasis in aging. Preface

21. Ficulle E, Sufian MDS, Tinelli C, Corbo M, Feligioni M (2018) Aging-related SUMOylation pattern in the cortex and blood plasma of wild type mice. Neurosci Lett 668:48-54. https://doi.org/10. 1016/j.neulet.2018.01.004

22. Schmidt AP, Lara DR, Souza DO (2007) Proposal of a guaninebased purinergic system in the mammalian central nervous system. Pharmacol Ther 116:401-416. https://doi.org/10.1016/j. pharmthera.2007.07.004

23. Lanznaster D, Dal-Cim T, Piermartiri TCB, Tasca CI (2016) Guanosine: a neuromodulator with therapeutic potential in brain disorders. Aging Dis 7:657-679. https://doi.org/10.14336/AD. 2016.0208

24. Tasca CI, Lanznaster D, Oliveira KA, Fernández-Dueñas V, Ciruela F (2018) Neuromodulatory effects of guanine-based purines in health and disease. Front Cell Neurosci 12:1-14. https:// doi.org/10.3389/fncel.2018.00376

25. Souza DG, Bellaver B, Bobermin LD, Souza DO, QuincozesSantos A (2016) Anti-aging effects of guanosine in glial cells. Purinergic Signal 12:697-706. https://doi.org/10.1007/s11302016-9533-4

26. Lanznaster D, Mack JM, Coelho V, Ganzella M, Almeida RF, DalCim T, Hansel G, Zimmer ER, Souza DO, Prediger RD, Tasca CI (2017) Guanosine prevents anhedonic-like behavior and impairment in hippocampal glutamate transport following amyloid- $\beta 1-$ 40 administration in mice. Mol Neurobiol 54:5482-5496. https:// doi.org/10.1007/s12035-016-0082-1

27. Schmidt AP, Lara DR, De Faria Maraschin J et al (2000) Guanosine and GMP prevent seizures induced by quinolinic acid in mice. Brain Res 864:40-43. https://doi.org/10.1016/S0006-8993(00) 02106-5

28. Hansel G, Tonon AC, Guella FL, Pettenuzzo LF, Duarte T, Duarte MMMF, Oses JP, Achaval M, Souza DO (2015) Guanosine protects against cortical focal ischemia. Involvement of inflammatory response. Mol Neurobiol 52:1791-1803. https://doi.org/10.1007/ s12035-014-8978-0

29. Dal-Cim T, Poluceno GG, Lanznaster D, de Oliveira KA, Nedel CB, Tasca CI (2019) Guanosine prevents oxidative damage and glutamate uptake impairment induced by oxygen/glucose deprivation in cortical astrocyte cultures: involvement of A1 and A2A adenosine receptors and PI3K, MEK, and PKC pathways. Purinergic Signal 15:465-476. https://doi.org/10.1007/s11302019-09679-w

30. Dal-Cim T, Molz S, Egea J, Parada E, Romero A, Budni J, Martín de Saavedra MD, Barrio L, Tasca CI, López MG (2012) Guanosine protects human neuroblastoma SH-SY5Y cells against mitochondrial oxidative stress by inducing heme oxigenase- 1 via PI3K/Akt/ GSK-3 $\beta$ pathway. Neurochem Int 61:397-404. https://doi.org/10. 1016/j.neuint.2012.05.021

31. Molz S, Dal-Cim T, Budni J, Martín-de-Saavedra MD, Egea J, Romero A, del Barrio L, Rodrigues ALS, López MG, Tasca CI (2011) Neuroprotective effect of guanosine against glutamateinduced cell death in rat hippocampal slices is mediated by the phosphatidylinositol-3 kinase/Akt/ glycogen synthase kinase $3 \beta$ pathway activation and inducible nitric oxide synthase inhibition. J Neurosci Res 89:1400-1408. https://doi.org/10.1002/jnr.22681

32. Di Iorio P, Ballerini P, Traversa U et al (2004) The antiapoptotic effect of guanosine is mediated by the activation of the PI 3-kinase/ AKT/PKB pathway in cultured rat astrocytes. Glia 46:356-368. https://doi.org/10.1002/glia.20002

33. Su C, Wang P, Jiang C et al (2013) Guanosine promotes proliferation of neural stem cells through cAMP-CREB pathway. J Biol Regul Homeost Agents 27:673-680 
34. Di Liberto V, Mudò G, Garozzo R et al (2016) The guanine-based purinergic system: the tale of an orphan neuromodulation. Front Pharmacol 7:1-15. https://doi.org/10.3389/fphar.2016.00158

35. Almeida RF, Comasseto DD, Ramos DB, Hansel G, Zimmer ER, Loureiro SO, Ganzella M, Souza DO (2017) Guanosine anxiolyticlike effect involves adenosinergic and glutamatergic neurotransmitter systems. Mol Neurobiol 54:423-436. https://doi.org/10.1007/ s12035-015-9660-x

36. Oliveira KA, Dal-Cim TA, Lopes FG, Nedel CB, Tasca CI (2017) Guanosine promotes cytotoxicity via adenosine receptors and induces apoptosis in temozolomide-treated A172 glioma cells. Purinergic Signal 13:305-318. https://doi.org/10.1007/s11302017-9562-7

37. Gerbatin RR, Dobrachinski F, Cassol G, Soares FAA, Royes LFF (2019) A1 rather than A2A adenosine receptor as a possible target of guanosine effects on mitochondrial dysfunction following traumatic brain injury in rats. Neurosci Lett 704:141-144. https://doi. org/10.1016/j.neulet.2019.04.014

38. Dobrachinski F, Gerbatin RR, Sartori G, Golombieski RM, Antoniazzi A, Nogueira CW, Royes LF, Fighera MR, Porciúncula LO, Cunha RA, Soares FAA (2019) Guanosine attenuates behavioral deficits after traumatic brain injury by modulation of adenosinergic receptors. Mol Neurobiol 56:3145-3158. https:// doi.org/10.1007/s12035-018-1296-1

39. Guo C, Hildick KL, Luo J, Dearden L, Wilkinson KA, Henley JM (2013) SENP3-mediated deSUMOylation of dynamin-related protein 1 promotes cell death following ischaemia. EMBO J 32:15141528. https://doi.org/10.1038/emboj.2013.65

40. Mendes-de-Aguiar CBN, Alchini R, Decker H, Alvarez-Silva M, Tasca CI, Trentin AG (2008) Thyroid hormone increases astrocytic glutamate uptake and protects astrocytes and neurons against glutamate toxicity. J Neurosci Res 86:3117-3125. https://doi.org/10. 1002/jnr.21755

41. Litsky ML, Hohl CM, Lucas JH, Jurkowitz MS (1999) Inosine and guanosine preserve neuronal and glial cell viability in mouse spinal cord cultures during chemical hypoxia. Brain Res 821:426-432. https://doi.org/10.1016/S0006-8993(99)01086-0

42. Thomaz DT, Dal-Cim TA, Martins WC, Cunha MP, Lanznaster D, de Bem AF, Tasca CI (2016) Guanosine prevents nitroxidative stress and recovers mitochondrial membrane potential disruption in hippocampal slices subjected to oxygen/glucose deprivation. Purinergic Signal 12:707-718. https://doi.org/10.1007/s11302016-9534-3

43. Romero-Calvo I, Ocón B, Martínez-Moya P, Suárez MD, Zarzuelo A, Martínez-Augustin O, de Medina FS (2010) Reversible Ponceau staining as a loading control alternative to actin in Western blots. Anal Biochem 401:318-320. https://doi.org/10.1016/j.ab.2010.02. 036

44. Fletcher-Jones A, Hildick KL, Evans AJ, Nakamura Y, Wilkinson KA, Henley JM (2019) The C-terminal helix 9 motif in rat cannabinoid receptor type 1 regulates axonal trafficking and surface expression. Elife 8:1-26. https://doi.org/10.7554/eLife.44252

45. Taylor P (2015) Immunofluorescence of cultured cells. Neuture Protoc Exch

46. Mosmann T (1983) Rapid colorimetric assay for cellular growth and survival: application to proliferation and cytotoxicity assays. J Immunol Methods 65:55-63. https://doi.org/10.1016/00221759(83)90303-4

47. Gurung S, Evans AJ, Wilkinson KA, Henley JM (2018) ADAR2mediated $\mathrm{Q} / \mathrm{R}$ editing of GluK2 regulates kainate receptor upscaling in response to suppression of synaptic activity. J Cell Sci 131. https://doi.org/10.1242/jcs.222273

48. Flotho A, Melchior F (2013) Sumoylation: a regulatory protein modification in health and disease. Annu Rev Biochem 82:357385. https://doi.org/10.1146/annurev-biochem-061909-093311
49. Hickey CM, Wilson NR, Hochstrasser M (2012) Function and regulation of SUMO proteases. 13:755-766. https://doi.org/10.1038/ nrm3478.Function

50. Verkhratsky A, Ho MS, Zorec R, Parpura V (2019) Neuroglia in neurodegenerative diseases

51. Matias I, Morgado J, Gomes FCA (2019) Astrocyte heterogeneity: impact to brain aging and disease. Front Aging Neurosci 11:1-18. https://doi.org/10.3389/fnagi.2019.00059

52. Saitoh H, Hinchey J (2000) Functional heterogeneity of small ubiquitin-related protein modifiers SUMO-1 versus SUMO-2/3. J Biol Chem 275:6252-6258. https://doi.org/10.1074/jbc.275.9. 6252

53. Li B, Gu L, Hertz L, Peng L (2013) Expression of nucleoside transporter in freshly isolated neurons and astrocytes from mouse brain. Neurochem Res 38:2351-2358. https://doi.org/10.1007/ s11064-013-1146-5

54. Pastor-Anglada M, Pérez-Torras S (2018) Emerging roles of nucleoside transporters. Front Pharmacol 9:1-8. https://doi.org/10.3389/ fphar.2018.00606

55. Martin S, Wilkinson KA, Nishimune A, Henley JM (2007) Emerging extranuclear roles of protein SUMOylation in neuronal function and dysfunction. Nat Rev Neurosci 8:948-959. https://doi. org/10.1038/nrn2276

56. Wilkinson KA, Nakamura Y, Henley JM (2010) Targets and consequences of protein SUMOylation in neurons. 64:195-212. https:// doi.org/10.1016/j.brainresrev.2010.04.002.Targets

57. Yang W, Paschen W (2009) Gene expression and cell growth are modified by silencing SUMO2 and SUMO3 expression. Biochem Biophys Res Commun 382:215-218. https://doi.org/10.1016/j. bbrc.2009.03.013

58. Datwyler AL, Lättig-Tünnemann G, Yang W, Paschen W, Lee SLL, Dirnagl U, Endres M, Harms C (2011) SUMO2/3 conjugation is an endogenous neuroprotective mechanism. J Cereb Blood Flow Metab 31:2152-2159. https://doi.org/10.1038/jcbfm.2011.112

59. Wang L, Ma Q, Yang W, Mackensen GB, Paschen W (2012) Moderate hypothermia induces marked increase in levels and nuclear accumulation of SUMO2/3-conjugated proteins in neurons. J Neurochem 123:349-359. https://doi.org/10.1111/j.1471-4159. 2012.07916.x

60. Bernstock JD, Ye D, Smith JA, Lee YJ, Gessler FA, Yasgar A, Kouznetsova J, Jadhav A, Wang Z, Pluchino S, Zheng W, Simeonov A, Hallenbeck JM, Yang W (2018) Quantitative highthroughput screening identifies cytoprotective molecules that enhance SUMO conjugation via the inhibition of SUMO-specific protease (SENP)2. FASEB J 32:1677-1691. https://doi.org/10. 1096/fj.201700711R

61. Tatham MH, Jaffray E, Vaughan OA, Desterro JMP, Botting CH, Naismith JH, Hay RT (2001) Polymeric chains of SUMO-2 and SUMO-3 are conjugated to protein substrates by SAE1/SAE2 and Ubc9. J Biol Chem 276:35368-35374. https://doi.org/10.1074/jbc. M104214200

62. Golebiowski F, Matic I, Tatham MH, Cole C, Yin Y, Nakamura A, Cox J, Barton GJ, Mann M, Hay RT (2009) System-wide changes to sumo modifications in response to heat shock. Sci Signal 2:ra24. https://doi.org/10.1126/scisignal.2000282

63. Vertegaal ACO, Andersen JS, Ogg SC, Hay RT, Mann M, Lamond $\mathrm{AI}$ (2006) Distinct and overlapping sets of SUMO-1 and SUMO-2 target proteins revealed by quantitative proteomics. Mol Cell Proteomics 5:2298-2310. https://doi.org/10.1074/mcp.M600212MCP200

64. Giuliani P, Ballerini P, Ciccarelli R, Buccella S, Romano S, D'Alimonte I, Poli A, Beraudi A, Peña E, Jiang S, Rathbone MP, Caciagli F, di Iorio P (2012) Tissue distribution and metabolism of guanosine in rats following intraperitoneal injection. J Biol Regul Homeost Agents 26:51-65 
65. Decker H, Piermartiri T, Nedel C, et al (2019) Guanosine and GMP increase the number of granular cerebellar neurons in culture: dependence on adenosine $\mathrm{A} 2 \mathrm{~A}$ and ionotropic glutamate receptors. 439-450

66. Li Q, Ye K, Blad CC, den Dulk H, Brouwer J, IJzerman AP, Beukers MW (2007) ZM241385, DPCPX, MRS1706 are inverse agonists with different relative intrinsic efficacies on constitutively active mutants of the human adenosine A2B receptor. J Pharmacol Exp Ther 320:637-645. https://doi.org/10.1124/jpet.106.111203

67. Lebon G, Warne T, Edwards PC, Bennett K, Langmead CJ, Leslie AGW, Tate CG (2011) Agonist-bound adenosine A2A receptor structures reveal common features of GPCR activation. Nature 474:521-526. https://doi.org/10.1038/nature10136

68. Safhi MMA, Rutherford C, Ledent C, Sands WA, Palmer TM (2010) Priming of signal transducer and activator of transcription proteins for cytokine-triggered polyubiquitylation and degradation by the A2A adenosine receptor. Mol Pharmacol 77:968-978. https://doi.org/10.1124/mol.109.062455

69. Lanznaster D, Massari CM, Marková V et al (2019) Adenosine A1A2A receptor-receptor interaction: contribution to guanosinemediated effects. Cells 8:1-16

70. Volpini R, Marucci G, Buccioni M, Dal Ben D, Lambertucci C, Lammi C, Mishra RC, Thomas A, Cristalli G (2011) Evidence for the existence of a specific $\mathrm{G}$ protein-coupled receptor activated by guanosine. ChemMedChem 6:1074-1080. https://doi.org/10.1002/ cmdc. 201100100

71. Ciccarelli R, Di Iorio P, D'Alimonte I et al (2000) Cultured astrocyte proliferation induced by extracellular guanosine involves endogenous adenosine and is raised by the co-presence of microglia. Glia 29:202-211. https://doi.org/10.1002/(SICI)10981136(20000201)29:3<202::AID-GLIA2>3.0.CO;2-C

72. Jackson EK, Cheng D, Jackson TC et al (2013) Extracellular guanosine regulates extracellular adenosine levels. Am J Physiol Cell Physiol 304:406-421

73. Krupnick JG, Benovic JL (1998) The role of receptor kinases and arrestins in G protein-coupled receptor regulation. Annu Rev Pharmacol Toxicol 38:289-319. https://doi.org/10.1146/annurev. pharmtox.38.1.289

74. Bünemann M, Hosey MM (1999) G-protein coupled receptor kinases as modulators of G-protein signalling. J Physiol 517:5-23. https://doi.org/10.1111/j.1469-7793.1999.0005z.x

75. Sheth S, Brito R, Mukherjea D, Rybak L, Ramkumar V (2014) Adenosine receptors: expression, function and regulation. Int $\mathrm{J}$ Mol Sci 15:2024-2052. https://doi.org/10.3390/ijms15022024
76. Liu Q, Li J, Khoury J, Colgan SP, Ibla JC (2009) Adenosine signaling mediates SUMO-1 modification of IKB $\alpha$ during hypoxia and reoxygenation. J Biol Chem 284:13686-13695. https://doi. org/10.1074/jbc.M809275200

77. Guo C, Henley JM (2014) Wrestling with stress: roles of protein SUMOylation and deSUMOylation in cell stress response. IUBMB Life 66:71-77. https://doi.org/10.1002/iub.1244

78. Henley JM, Carmichael RE, Wilkinson KA (2018) Extranuclear SUMOylation in neurons. Trends Neurosci 41:198-210. https:// doi.org/10.1016/j.tins.2018.02.004

79. Khattar M, Song K, Grossman S et al (2019) Abstract 3252: TAK981: a first in class SUMO inhibitor in phase 1 trials that promotes dendritic cell activation, antigen-presentation, and $\mathrm{T}$ cell priming. Cancer Res 79:3252 LP - 3252. https://doi.org/10.1158/15387445.AM2019-3252

80. Fukuda I, Ito A, Hirai G, Nishimura S, Kawasaki H, Saitoh H, Kimura KI, Sodeoka M, Yoshida M (2009) Ginkgolic acid inhibits protein SUMOylation by blocking formation of the E1-SUMO intermediate. Chem Biol 16:133-140. https://doi.org/10.1016/j. chembiol.2009.01.009

81. Suzawa M, Miranda DA, Ramos KA, Ang KKH, Faivre EJ, Wilson CG, Caboni L, Arkin MR, Kim YS, Fletterick RJ, Diaz A, Schneekloth JS Jr, Ingraham HA (2015) A gene-expression screen identifies a non-toxic sumoylation inhibitor that mimics SUMOless human LRH-1 in liver. Elife 4:1-22. https://doi.org/10.7554/ eLife.09003

82. Rathbone M, Pilutti L, Caciagli F, Jiang S (2008) Neurotrophic effects of extracellular guanosine. Nucleosides Nucleotides Nucleic Acids 27:666-672. https://doi.org/10.1080/ 15257770802143913

83. Bettio LEB, Gil-Mohapel J, Rodrigues ALS (2016) Guanosine and its role in neuropathologies. Purinergic Signal 12:411-426. https:// doi.org/10.1007/s11302-016-9509-4

84. Hoppe JB, Rattray M, Tu H, Salbego CG, Cimarosti H (2013) SUMO-1 conjugation blocks beta-amyloid-induced astrocyte reactivity. Neurosci Lett 546:51-56. https://doi.org/10.1016/j.neulet. 2013.04.050

Publisher's note Springer Nature remains neutral with regard to jurisdictional claims in published maps and institutional affiliations. 